\title{
Shadow Economy and Economic Growth
}

\author{
Hedhli Mayssa, Arafet Hamida, Zouhaier Hadhek*, Fatma Mrad and Farhat Haouat
}

Higher Institute of Management of Gabes, Tunisia.

\begin{abstract}
This work provides an opportunity to analyze the relationship between the informal economy and economic growth, the methodology used is inspired by the work of Friedrich schneider_(2018). To this end, we empirically address this point using an econometric model over the period 1996-2015. From the model prediction, we find the existence of a negative causal effect of the Shadow economy on economic growth. Our results state that the simultaneous effect of the Shadow economy and the rule of law variables and regulatory quality are negative. The size of the informal sector depends positively on tax law indicators and government policies and regulations, and an increase in the size of the informal sector is detrimental to growth.
\end{abstract}

Keywords: Economy, growth, informal trade.

\section{INTRODUCTION.}

The shadow economy groups together many activities ranging from legal activities carried out illegally (not controlled by the State and not subject to tax) to illegal activities. It has found illegal activities in practically all the countries of the world $_{2}$ whatever its level of development, be it rich, in transition or poor but with different percentages. Until the year 2015 , the underground economy according to the data presented by the World Bank on the share of shadow economies varies. An average of $10 \%$ of the GDP in the developed countries like in Europe, taking also into account the United States, with a percentage of $8.4 \%$ also Japan with a percentage of $10.3 \%$, France $14.7 \%$ and China $12.8 \%$. In developing countries, especially African nations this kind of activity is much higher than that of developed countries, the percentage of the shadow economy in the GDP is around $40 \%$ or more, Among these countries we find Tanzania with a percentage of $54.8 \%$, Thailand $51.1 \%$ and Egypt $33.5 \%$. These obscurities have become one of the major issues of economic equity in the global community.

Although this problem is exceedingly difficult to study properly, since it is almost impossible to identify the direction and methods of solving these kinds of social, professional and economic problems linked to the irregular sector. But overview of all empirical work research has been developed on the size and development of the global shadow economy (Feld and Schneider 2010, Gerxhani 2003, Schneider 2011, 2015, 2017, Schneider and Williams 2013, Williams and Schneider 2016, and Hassan and Schneider 2016).

The influence of the shadow economy on economic growth is the subject of much attention around the world certain questions need to be addressed: what is the effect of the in

*Address correspondence to this author at Higher Institute of Management of Gabès, Tunisia; Tel: 0021697388013, 0021622576464;

E mail: hzouhair2000@yahoo.fr formal economy on economic growth, and by what mechanisms can this type of activity influence the formal economy? Several studies have been put forward on the relationship between the underground economy and economic, growth such as Djankov et al. (2002), (Loayza, 1996; Arimah, 2001; Zaman and Goschin, 2015; Borlea et al., 2017; Jerzmanowski, 2017;Mandroshchenko et al., 2018). These authors have studied this phenomenon in order to discover if this kind of activity could be a source of economic growth or depression while specifying the specific parameters of the "shadow economy", while also revealing the regularities and characteristics of development and to identify and assess the factors stimulating economic growth. The results obtained by this research were based on scientific research methods such as empirical, historical and theoretical methods. Economic and statistical methods are also used in the study. Among the main results identified by the authors, the development of the underground economy has both negative and positive consequences on economic growth. From a positive point of view the authors find that there is income preventing the underground economy from being exploited in the legal economy, when $_{2}$ for example, informal sector entrepreneurs use government corruption to avoid administrative regulations. However, several other researchers defend the idea that the underground economy can influence the official economy only negatively, tax evasion and failure to contribute to public spending can only lead to economic depression.

Through this research work, we will try to examine the effect of parallel activity on economic growth. The objective of this research is to establish whether the underground economy has a positive or negative influence on the economy of the countries while taking into account the percentage of shadow activity in the real GDP per capita (Friedrich Schneider (2018)).

In order to achieve these goals, the article is organized as follows. The first section, through a review of the literature, recalls the impact of the underground economy on growth, 
the second, a presentation of the methodology, data, technique and discussion of estimation results as well as a conclusion.

\section{THEORETICAL CONSIDERATIONS}

\subsection{Definition of the Shadow Economy}

To study the phenomenon of the shadow economy one must first understand the meaning of this concept. Some have qualified this term as underground economy by the economy "illegal", "extralegal", "underground", "criminal", "informal", "shadow", etc. This results in terminological confusion.

Really there is a great difficulty to define or even to interpret this phenomenon, each researcher can understand and interpret this term differently. According to Olga Mandroshchenko (2018), the analysis of this concept of the informal economy necessarily requires and above all a classification of approaches (A legal approach, Accounting and statistics, criminological and complex approach). These approaches bring together several criteria: legal, statistical, economic, social and ethical. So according to the author "underground economy is a set of relationships between individuals, groups of individuals, institutional units of production, distribution, redistribution, exchange and consumption of material goods and services. The results are not captured by official statistics or included in the "National Product". Therefore, the underground economy is a source of undeclared income from the production or marketing of legal goods and services that should normally be taxable if they were declared to the tax authorities. (Schneider, Williams, 2013).

Further, Ottervik (2013) defined the shadow economy as "the set of legal economic activities that should be included in national income accounts, but in the absence of avoidance strategies, these market economies are linked to tax evasion and social security contributions as well as non-compliance with regulations (official working hours, security rules and social security fraud).

\subsection{The Shadow Economy and Economic Growth}

Economic growth is considered a well-determined objective for all nations and is a phenomenon measured statistically on the basis of economic indicators such as GDP and GNP. But still, there are problems to achieve it especially at the level of poorer countries due to the constant historical evolution, the updating of the regularities and the mechanisms of social reproduction. While the quantitative index of economic growth is incorrect (too low) in the event that the irregular sector of the economy is excluded.

In general, this shadow phenomenon is present in absolutely all economies. It is a multifaceted subject and quite complicated for research.

The concept of the informal sector has appeared for more than four decades through observations made in the field. Several researchers have worked on this problem and among the new studies concerning this subject we find thank you very much my dear friend $\mathrm{c}$ is very nice. looking forward to your visit to Tunisia, for example, Olga Mandroshchenko (2018) whose objective was to understand the influence of the underground economy on economic growth in Russia. Several reasons were at the origin of this research, one can quote, the report of the World Federation of Trade Unions (WFTU), which suggests that the growth of the shadow economy in Russia is a consequence of the global financial crisis in 2008-2009. According to the author, there is not really a firm answer as to the effect of the informal economy on economic growth. Some researchers are convinced that the shadow phenomenon causes problems at the macro and micro-economic scale and social problems

Other researchers argue that the shadow economy causes a positive short-term effect on general economic policy. Therefore, any socio-economic phenomenon or process can have its advantages and disadvantages, and the underground economy is no exception because its nature is also twofold. Although a number of researchers suggest a positive influence of the underground economy on the country's economic growth, although most stress its negative aspects. Yet, the underground economy could play a role of a stabilization mechanism both nationally and globally. The fact that the "economic shadow" affects the GNP and the GDP cannot be disputed less because a very significant number of the goods produced by the "informal activity" are not always recorded by official statistics, but increase the well-being of the country.

According to Olga Mandroshchenko (2018), to solve the problem of the shadow economy, one must first identify the factors affecting the size of the shadow such as taxation, the maximum rate of income tax, index perception of corruption. The econometric calculations carried out have shown a strong correlation between the size of the informal sector and the indicators given.

Among the results released by the author, we find that the underground economy negatively affects the competition regime, distorts the market mechanism and distorts the tax system. In addition, the parallel relations of shadow activity influence the state of public finances, reduce the budget and also change the structure and the budgetary sphere of the state. We are talking here about a partial or total deterioration of a macroeconomic policy.

In terms of investment, parallel economic activity causes ambiguity in the investment process since, on the one hand, it can create invisible barriers to improving the efficiency of legal investors, and on the other hand, fictitious producers (investors in shadow activity) who do not invest in R\&D. According to the author, there can also be a serious effect on the consumption structure of people, income is distributed illegally and not recorded. Also ghost companies violate the rights of consumers.

Parallel economic phenomena negatively affect the labor market resulting in unjustified unemployment and employees without social security.

Generally speaking, the underground economy has a negative influence on the process of international and national economic relations and is considered by the author as an obstacle to the implementation of reforms.

But Olga Mandroshchenko (2018) finds that the phenomenon of the shadow economy is socio-economic it can have advantages as well as disadvantages and among the benefits 
of the underground economy that the participants of the shadow business have more opportunities to increase their income, an increase in GDP can be produced through this phenomenon.

Parallel economic activity positively affects the labor market through the creation of jobs and new sources of income, an improvement in the financial situation of the population, therefore fictitious income is invested in the financial sectors of the formal economy.

On the social level, phantom relationships reduce social tensions as well as soften unwanted social contradictions between rich and poor. The shadow activity helps to balance the extreme inequality of income of the population.

In general, the authors ${ }^{1}$ show that the shadow economy can have effects on economic growth. The characteristics of the shadow economy phenomenon depend above all on the level of economic development of the country, the institutional framework and the regulatory role of the economy state in the community. Hence each country treats this problem in a different way according to its specificities.

\section{Models and Estimates.}

Based on the considerations cited and the different opinions given regarding the overall effect of the underground economy on economic growth, our objective in this empirical part is to examine the impact of the underground economy represented in the model. Estimated by (X4) on economic growth (Y). A main hypothesis will be proposed:

Hypothesis: the underground economy influences economic growth positively or negatively? And through which channels?

The chosen sample will be based on the research made by Friedrich Schneider (2017), a new estimation method adopted by the author to calculate the percentage of the underground economy of GDP in 158 countries around the world over the period 1991-2015.

Our analytical sample only covers 51 countries, the sample includes 18 developed countries whose percentage of the shadow economy in the GDP is less than 20\% which represents the World Bank threshold. 33 poor and developing countries, the percentage of the informal economy in the GDP of these countries is greater than $20 \%$. The variables used in our estimation models are:

\section{- Endogenous variable}

$\mathrm{Y}$ is the endogenous variable, represents the real GDP growth rate per capita for each country in the sample and for each year of the analysis period.

- Control variables, values are in percentage of real GDP per capita:

$\mathrm{X} 1$ : the gross fixed capital formation. (inv)

$\mathrm{X} 2$ : inflation. (inf)

\footnotetext{
${ }^{1}$ To the best of our knowledge, a set of empirical works which have taken into account the effet of the shadow economy on economic growth can be found in the table 1, Appendix A
}

X3: commercial opening. (trade)

\section{- Variable of interest}

$\mathrm{X} 4$ is the size of the underground economy as a percentage of real GDP per capita, also named (eco inf).

- Governance variables:

X5: control of corruption: According to the definition published by the World Bank "Corruption control captures perceptions of the extent to which public power is exercised for private gain, including small and large forms of corruption, as well as" capture " of the state by elites and private interests. The estimate gives the country's score on the aggregate indicator, in units of a standard normal distribution, that is, ranging from about -2.5 to 2.5 . "

X6: governorate efficiency: according to the World Bank this variable "reflects perceptions of the quality of public services, the quality of the public service and the degree of its independence vis-à-vis political pressure, the formulation and implementation of policies; and the credibility of the government's commitment to these policies. The estimate gives the country's score on the aggregate indicator, in units of a standard normal distribution, i.e. ranging from approximately -2.5 to 2.5 "

X7: political stability: the definition published by the World Bank "Political stability and the absence of violence / terrorism measures the perception of the likelihood of political instability and / or politically motivated violence, including terrorism. The estimate gives the country's score on the aggregate indicator, in units of a standard normal distribution, that is, ranging from about -2.5 to 2.5. "

X8: Regulatory quality: "Regulatory quality reflects the perception of the government's ability to formulate and implement strong policies and regulations that enable and promote private sector development. The estimate gives the country's score on the aggregate indicator, in units of a standard normal distribution, that is, ranging from about -2.5 to 2.5 . "

X9: Rule of law: "the quality of contract enforcement, property rights, police and courts, as well as the likelihood of crime and violence." The estimate gives the country's score on the aggregate indicator, in units of a standard normal distribution, that is, ranging from about -2.5 to 2.5 . "

$\mathrm{So}_{2}$ the general form of the equation to be estimated is as follows:

$$
\begin{aligned}
& \mathrm{Y}_{i, t}=\alpha+x_{i t} \beta+\varepsilon_{\mathrm{it}} \\
& \mathrm{t}=1996 ;---; 2015 \\
& \mathrm{i}=1 ;---; 51
\end{aligned}
$$

-Test of Auto corrélation between variables. 2

According to this matrix, we find a strong correlation between the governance variables: governorate efficiency (X6), political stability (X7), quality of regulation (X8), Rule of

\footnotetext{
${ }^{2}$ Here, we can of course weigh the autocorrelation test of variables table2, Appendix B.
} 
law (X9). On this basis, to avoid multi-collinearity, we will avoid intervening these variables together in our equation.

\subsection{Direct Effect of the Shadow Economy on Economic Growth}

\subsubsection{Model and Estimation}

In the following example, we will make an estimate to know the impact of the underground economy on the economic growth of real GDP per capita, we will focus our attention on a sample of 51 countries, observed over the period 19962015. The dependent variable measures the growth of real GDP per capita. The indicator of the underground economy is represented by values calculated by Friedrich Schneider (2018) expressed as a percentage of GDP. Three control variables: inflation, gross fixed capital formation and the degree of openness of the economy; all variables are percentages of real GDP per capita.

So: $\boldsymbol{L 1}: Y_{i t}=\alpha_{i}+\beta_{1} \ln X_{1 i, t}+\beta_{2} \ln X_{2 i, t}+\beta_{3} \ln X_{3 i, t}+\beta_{4} \ln X$ $4 i, t+\varepsilon_{i, t}$

- Where $\mathrm{Y}$ is the endogenous variable, represents the real GDP growth rate per capita for each country in the sample and for each year of the analysis period.

- $\mathrm{X} 1, \mathrm{X} 2$ and $\mathrm{X} 3$ are considered as control variables, all values are in percentage of real GDP per capita and they represent respectively, gross fixed capital formation, inflation and trade openness.

- X4 is the size of the underground economy as a percentage of real GDP per capita.

Table 3, presents all the estimation results obtained on the effect of the shadow economy on the economic growth of countries 3

\subsubsection{Discussion}

We accept the presence of an AR (1) effect for the residues and accept the absence of an AR (2) effect. This is in accordance with the assumptions made. In addition, Sargan's tests validate the choice of instruments.

The estimation results show that the coefficients associated with the variables measuring: investment, inflation and trade openness are positive and statistically significant table 3 .

Investment is a confirmed growths engine of economic growth, hence an expected result of our study on the effect of investment on economic growth.

Economic openness today seems to be a catalyst for economic growth all over the world. Jacquot Yves-Marie, Schwander Jérôme (2000) through their observation concerning the effect of international trade on growth by classifying the economic performances of the main developing countries according to the degree of openness of their economy, they concluded that openness of an economy is empirically favorable to growth, but everything always depends on a country's

\footnotetext{
${ }^{3}$ For a detailed presentation of the results over all variables see Table 3 , of the Appendix C.
}

level of development. International trade is therefore one of the main engines of economic growth.

The positive effect of inflation on growth observed in our obtained result table 3 is aligned with the study of Mubarik (2005) namely low and stable inflation stimulates economic growth. Several other empirical studies have examined the relationship between inflation and long-term economic growth and have found that the latter may be non-linear. The possibility of non-linearity was first identified by Fischer (1993), Sarel (1996) specifically tested the existence of a structural break in the relationship between inflation and economic growth.

The coefficient associated with our variable of interest, the underground economy table 3 are significant at the $1 \%$ level and the coefficients is $(-0.089)$ therefore we are talking about an inverse effect of the shadow economy on economic growth. Any increase in shadow activity leads to a deterioration in the performance of the national economy. The results of this study are confirmed by certain studies of the literature, namely Loayza (1996), according to the author the informal sector is one of the causes of economic depression, under the pretext that this kind of informal activity affects the public service by poorly operating and reducing its availability to everyone. Olga Mandroshchenko (2018), the informal economy can harm economic growth, but according to Olga, this remains theoretically because there is a very significant weight of unregistered production in the official economy, but it increases the well-being of the country.

\section{2. interaction between Shadow Economy and Govern- ance Variable}

\subsubsection{Model and Estimation.}

On the same sample of 51 countries, we are going to make a third estimate where by adding what are called interactive variables in the form of exogenous variables. An interaction effect appears when a relationship between two variables is modified by another variable. In other words, the strength of the relationship between two variables is different depending on the value of other variables Fisher (1926).

Thanks to the integration of these interactive variables we can test the simultaneous influence of two variables each time $\mathrm{X} 4$ with the other variables alternately, let X1, X2, X3, $\mathrm{X} 5, \mathrm{X} 6, \mathrm{X} 7, \mathrm{X} 8$ and $\mathrm{X} 9$ on " $\mathrm{y}$ " the endogenous variable which is not additive.

The interaction between the underground economy (X4) and the chosen variable named "XP" carrying the basic model. The effect of the underground economy $(\beta 4)$ is a function of variable chooses:

$$
\beta_{4}=\mathrm{a}+\mathrm{b} \mathrm{X}_{\mathrm{P}}
$$

Where $\mathrm{a}$ and $\mathrm{b}$ are estimated numbers.

- $\quad \mathrm{a}=\beta 4$ if and only if $\mathrm{X}_{\mathrm{p}}=0$

- $\quad b$ is a coefficient which means that the effect of the underground economy $\beta 4$ changes if the variable $X_{p}$ rises by one.

By replacing in the initial equation $\beta 4$ by its equivalent $\mathrm{a}+$ $\mathrm{bX}$; we obtain 
$\boldsymbol{y}=\alpha_{i}+\beta_{1} \ln X_{1 i, t}+\beta_{2} \ln X_{2 i, t}+\beta_{3} \ln X_{3 i, t}+\left(\mathrm{a}+b X_{\mathrm{p}}\right) \ln X_{4 i, t}+$ $\varepsilon_{t}$

$\mathbf{y}=\alpha_{\mathrm{i}}+\beta_{1} \ln X_{1 \mathrm{i}, \mathrm{t}}+\beta_{2} \ln X_{2 \mathrm{i}, \mathrm{t}}+\beta_{3} \ln X_{3 \mathrm{i}, \mathrm{t}}+\left[a \ln X_{4 i, \mathrm{t}}\right.$ $\left.+\left(b X_{p}\right) \ln X_{4 i, t}\right]+\varepsilon_{t}$

By changing the order of the elements and returning to the usual notation, we have in an equivalent way:

$\mathbf{y}=\alpha_{\mathrm{i}}+\beta_{1} \ln X_{1 \mathrm{i}, \mathrm{t}}+\beta_{2} \ln X_{2 \mathrm{i}, \mathrm{t}}+\beta_{3} \ln X_{3 \mathrm{i}, \mathrm{t}}+\beta_{4} \ln X_{4 i, t}+\beta^{\prime}{ }_{1} \ln$ $X_{1 i, t}^{\prime}+\ldots \ldots+\beta_{x}{ }_{x} \ln X_{x i, t}+\varepsilon_{t}$

$\mathbf{x}=1 ; \ldots \ldots \ldots ; \mathbf{9}$ except $\left(X_{4}\right.$ represents our variable of interest, i.e. the shadow economy).

The new regression equation therefore contains the control variables, our variable of interest being the shadow economy and the new variables, defined as being the product of $\mathrm{X}_{4}$ and $\mathrm{X}_{\mathrm{P}}$. to each of these terms is associated, as usual, a regression coefficient, denoted $\beta_{1}, \beta_{2}, \beta_{3}$ for the control variables, $\beta_{4}$ the coefficient associated with our variable of interest, namely the shadow economy and $\beta^{\prime} 1, \beta^{\prime}{ }_{2}, \ldots \ldots, \beta_{9}^{\prime}$ are the coefficients associated with our interactive variables.

Whose-:

Where $\mathrm{Y}$ is the endogenous variable, represents the real GDP growth rate per capita for each country in the sample and for each year of the analysis period.

$\mathrm{X}^{\prime} 1$ : represents the relationship between the shadow economy and the gross fixed capital formation, $(\mathrm{X} 4 * \mathrm{X} 1)$.

$\mathrm{X}^{\prime} 2$ : represents the relationship between the shadow economy and inflation, $(\mathrm{X} 4 * \mathrm{X} 2)$.

$X^{\prime} 3$ : represents the relationship between the shadow economy and commercial exchanges, $(\mathrm{X} 4 * \mathrm{X} 3)$.

$X^{\prime} 5$ : represents the relationship between the shadow economy and corruption $(\mathrm{X} 4 * \mathrm{X} 5)$.

$X$ '6: represents the relationship between the shadow economy and government efficiency, $(\mathrm{X} 4 * \mathrm{X} 6)$.

$X^{\prime} 7$ : represents the relationship between the shadow economy and political stability, $(\mathrm{X} 4 * \mathrm{X} 7)$.

$X^{\prime} 8$ : represents the relationship between the shadow economy and regulatory quality, $(\mathrm{X} 4 * \mathrm{X} 8)$.

$X$ '9: represents the relationship between the shadow economy and the rule of law, $(\mathrm{X} 4 * \mathrm{X} 9)$.

Table 4 the simultaneous effect of the underground economy and the set of governance variables on economic growth. the objective of this work is to know through which channels the black economy can influence growth4

\subsubsection{Discussion}

On the statistical side, the results of the estimated parameters are consistent with the economic intuition from which we accept the presence of an AR effect (1) for the residuals and the absence of an AR effect (2). The choice of instruments is valid according to the Sargan test.

\footnotetext{
${ }^{4}$ The set of empirical results obtained is found in table 4, Appendix D.
}

Always a positive effect of investment, economic openness and inflation on economic growth of real GDP per capita.

Following the integration of interactive variable (1), to study the simultaneous effect of the shadow economy and corruption on economic growth, the results show a positive effect of this variable with a coefficient of 0.018 (Table 4). Therefore, having a simultaneous positive effect on economic growth shows the negative correlation between the shadow economy and corruption among the causes that may be at the origin of this relationship that entrepreneurs may bribe officials in order to obtain contract from the public sector and therefore, such contract is conducted in the official sector only. Therefore, increasing corruption could be associated with a decrease in shadow economy in exchange, with a move the official economy and thus an economic growth may occur (Nicolae and al 2017). Also the effects on growth depend in part on the reintegration into the official economy of unreported earnings. Some economists estimate that around $2 / 3$ of corruption derived from the informal activity of the shadow economy would be reintroduced into economic circuits, particularly in the form of consumption or investment.

Interactive variable (2), examines the simultaneous effect of the shadow economy and investment table 4 shows a positive effect so any increase in investment generates a decrease in informal activity which improves the economic situation of nations.

Regarding the tested simultaneous effect of the underground economy and inflation on economic growth Interactive variable (3) table 4, the Simultaneous effect of inflation and the shadow economy on economic growth is positive, a coefficient of 0.002. A simultaneous positive effect on economic growth shows the negative effect between inflation and the underground economy so having an optimal inflation rate in a country could be an indirect mechanism of taxation of the informal economy Nicolini (1998),

After having integrated into the estimation models the interactive variable (4) table4 the simultaneous effect of openness and the underground economy on economic growth is negative. We can see that openness to the outside can encourage informal activity. Countries that are too open to the outside suffer from the problem of the underground economy much more than other less open countries.

The interactive variables (7) table 4 , which combine the simultaneous effect of the shadow economy with the quality of regulation, the variables are significant at the $1 \%$ level and the coefficients is 0.015 have a simultaneous negative effect on economic growth shows that the quality of regulation and among the factors that encourage the underground economy. Also, the rule of law can be a very important cause of the increase of the shadow economy we observe a simultaneous negative effect of the underground economy and a variable of governance (rule of law) interactive variables (8) table 4. So, we can show that Countries with high tax rates, numerous laws and regulations, and poor rule of law suffer more than other countries from the problem of the underground economy, and tax evasion is one of the main causes of this problem. Kind of shadow activity. This subsequently causes the slowdown in economic growth. 
These findings are in line with those of Tedika \& Mutascu (2013), through a panel data econometrics model tested the effects of the informal economy on tax revenues, a sample of several African countries for the period 1999-2007, the authors have identified that the informal economy has a significant and negative impact on tax revenues. In addition, the widening of the underground economy phenomenon generates a remarkable reduction in the level of tax revenues. The primary objective of these African countries is therefore to control the level of the underground economy in order to maximize the tax revenue collected.

The reduction of this type of activity, according to the authors, requires on the one hand an improvement in the laws concerning the prevention of tax evasion, in parallel with a rigorous tax control. On the other hand, encouraging companies to switch from the informal economy to an official economy through corrections in the tax law rules.

Loayza (1996) through an empirical study the author estimates the size of the informal economy in Latin America and its effect on endogenous growth. Loayza finds that there is a positive relationship between the informal economy and the tax burden. The increase in the size of the informal sector negatively influences economic growth.

\section{CONCLUSION}

The informal sector is not negligible and it can harm economies. We have revealed through this study that despite the different ideas and opinions that the negative or positive effect of the underground economy has on the economic growth of countries, unfortunately, the shadow economy negatively influences the well-being of the population. According to the results obtained, the main axes on which we can help decision makers to master the percentage of the shadow economy in the GDP is that they must encourage investment have an optimal threshold of inflation and manage the country's degree of openness.

$\mathrm{Also}_{2}$ the increase in the informal economy remains dependent on the indicators of the tax burden because tax evasion is one of the causes that push people to practice this kind of activities in the shadows. The government's ability to formulate and implement sound policies and regulations that enable and promote private sector development and restrictions on the labor market are also seen as the growth engine of the informal sector, which in turn leads to an economic depression, unavailability and poor exploitation of public services, lack of public investment and discouragement and overwhelming private investors.

\section{WEB SPELLING}

World Bank website (consulted several times)

\section{CONFLICT OF INTEREST STATEMENT}

The authors declare that they have no conflict of interest.

\section{APPENDIX A}

Table 1. A Review of the Literature: the Effect of the Shadow Economy on Economic Growth.

\begin{tabular}{|c|c|c|}
\hline Authors & Empirical Work & Results Obtained \\
\hline Loayza (1996) & $\begin{array}{l}\text { Determinants of the under- } \\
\text { ground economy and its } \\
\text { effect on economic growth in } \\
\text { Latin American countries }\end{array}$ & $\begin{array}{l}\text { The results generated by this work show that: } \\
\text { Indicators of fiscal pressure and restrictions on the labor market have a positive effect on the } \\
\text { size of the informal sector, while the quality of government institutions influences it negatively. } \\
\text { Any increase in the size of the informal sector causes economic depression by reducing the } \\
\text { availability of public services, and by increasing the number of activities that use some existing } \\
\text { public services less effectively or not at all. }\end{array}$ \\
\hline Djankov, al (2002) & $\begin{array}{l}\text { This research examines data } \\
\text { on entry regulation for start- } \\
\text { ups in } 75 \text { countries }\end{array}$ & $\begin{array}{l}\text { Among the results obtained, in most of the countries in the sample the official entry fees are } \\
\text { extremely high. } \\
\text { In countries where regulations are very strict, the level of corruption is too high and the size of } \\
\text { the underground economy is very large with poor quality of public and private goods. On the } \\
\text { other hand, countries with democratic governments, entry regulations are more flexible, the } \\
\text { level of corruption and the underground economy is low. }\end{array}$ \\
\hline Arimah (2001) & $\begin{array}{l}\text { This article provides a quan- } \\
\text { titative analysis of the nature } \\
\text { of informal sector linkages } \\
\text { with the formal sector in } \\
\text { Nigeria. }\end{array}$ & $\begin{array}{l}\text { There is a relationship both upstream and downstream between the formal and informal sector: } \\
\text { Upstream: that is to say, monetary and real flows paid from the formal sector to the informal } \\
\text { sector. } \\
\text { Downstream: downstream links can be in the form of sub-agreements on the one hand. - con- } \\
\text { tracting with large national corporations, government agencies and foreign companies, on the } \\
\text { other hand this relationship is justified by the supply of consumer goods paid by the informal } \\
\text { sector to the formal sector. }\end{array}$ \\
\hline
\end{tabular}




\begin{tabular}{|c|c|c|}
\hline $\begin{array}{c}\text { Gheorghe Zamana, Zizi } \\
\text { Goschin (2015). }\end{array}$ & $\begin{array}{l}\text { This empirical study shows } \\
\text { the relationship between the } \\
\text { underground economy and } \\
\text { economic growth in Romania }\end{array}$ & $\begin{array}{l}\text { The synthetic index calculations state that Romania is not one of the countries with a very large } \\
\text { underground economy, so the underground economy index values are low and stable over the } \\
\text { period 1999-2012. } \\
\text { OLS regressions have shown that there is no significant influence of the underground economy } \\
\text { on economic growth. }\end{array}$ \\
\hline Borlea, al (2017) & $\begin{array}{l}\text { the relations between corrup- } \\
\text { tion and the underground } \\
\text { economy between the coun- } \\
\text { tries of the European Union } \\
\text { and the simultaneous effect } \\
\text { of these two variables on } \\
\text { economic growth }\end{array}$ & $\begin{array}{l}\text { The empirical results of this research justify the existence of an important and positive relation- } \\
\text { ship between corruption and the underground economy, the increase in corruption necessarily } \\
\text { implies a higher level of shadow economy. Regarding the simultaneous effect of the influence } \\
\text { of corruption and the shadow economy on economic growth, studies have shown that there is } \\
\text { both a high and a negative relationship. This means that the increasing level of corruption and } \\
\text { the underground economy negatively influences economic growth. }\end{array}$ \\
\hline $\begin{array}{l}\text { Friedrich Schneider, al } \\
\qquad(2017)\end{array}$ & $\begin{array}{l}\text { The article seeks to show the } \\
\text { impact of the underground or } \\
\text { shadow economy on eco- } \\
\text { nomic growth in the United } \\
\text { States during the period } 1870 \\
\text { to } 2014\end{array}$ & $\begin{array}{l}\text { The results obtained by this empirical work suggest that the effect of the underground economy } \\
\text { on growth before the world war is not the same after. Before the war it negatively influences } \\
\text { economic growth but after the underground economy has more and more a positive effect on } \\
\text { growth }\end{array}$ \\
\hline $\begin{array}{l}\text { Bettina Hametner, Frie- } \\
\text { drich Schneider (2014) }\end{array}$ & $\begin{array}{l}\text { The development of the } \\
\text { Colombian underground } \\
\text { economy and its effect on the } \\
\text { official GDP }\end{array}$ & $\begin{array}{l}\text { A remarkable increase in the underground economy over this period. The main factors that } \\
\text { stimulate the underground economy are unemployment and taxation. } \\
\text { By analyzing the relationship between shadow activities and the official economy, the author } \\
\text { finds that the underground economy has a positive effect on the official one. This result is justi- } \\
\text { fied by the increase in official GDP per capita over this period by a percentage of } 1.11 \% \text { and the } \\
\text { underground economy participates in this growth on average between } 0.09 \text { and } 0.27 \text { percentage } \\
\text { point. }\end{array}$ \\
\hline
\end{tabular}

\section{APPENDIX B}

Table 2. Self-Correlation Matrix of Variables (Appendix B).

\begin{tabular}{|c|c|c|c|c|c|c|c|c|c|}
\hline & $\mathrm{X} 4$ & $\mathrm{X} 1$ & $\mathrm{X} 2$ & $\mathrm{X} 3$ & $\mathrm{X} 5$ & $\mathrm{X} 6$ & $\mathrm{X} 7$ & $\mathrm{X} 8$ & $\mathrm{X} 9$ \\
\hline $\mathrm{X} 4$ & 1,000 & & & & & & \\
\hline $\mathrm{X} 1$ & -0.104 & 1,000 & & & & & \\
\hline $\mathrm{X} 2$ & 0.063 & -0.036 & 1.000 & & & & \\
\hline $\mathrm{X} 3$ & -0.255 & 0.039 & -0.036 & 1,000 & & & & \\
\hline $\mathrm{X} 5$ & -0.174 & 0.023 & -0.030 & 0.078 & 1.000 & & & \\
\hline $\mathrm{X} 6$ & -0.826 & 0.103 & -0.086 & 0.336 & 0.134 & 1,000 & & \\
\hline $\mathrm{X} 7$ & -0.712 & 0.085 & -0.039 & 0.320 & 0.159 & 0.808 & 1.000 & \\
\hline $\mathrm{X} 8$ & -0.765 & 0.062 & -0.119 & 0.351 & 0.162 & 0.921 & 0.728 & 1,000 & \\
\hline $\mathrm{X} 9$ & -0.843 & 0.088 & -0.084 & 0.293 & 0.189 & 0.961 & 0.830 & 0.927 & 1,000 \\
\hline
\end{tabular}

Source: Own calculations.

\section{APPENDIX C}

Table 3. Estimation Results.

\begin{tabular}{|c|c|c|}
\hline Variables & Estimation results \\
\hline inv. & & 0.054 \\
& & $0.000 *$ \\
\hline
\end{tabular}




\begin{tabular}{|c|c|c|}
\hline inf. & & 0.104 \\
\hline Trade & & $0.000 *$ \\
\hline Eco inf. & & 0.010 \\
\hline AR (1) & & -0.000 \\
\hline AR (2) & & $0.000 * 9$ \\
\hline Sargan & & -4.478 \\
\hline
\end{tabular}

Note: $* * * \mathrm{p}<0.01, * * \mathrm{p}<0.05, * \mathrm{p}<0.1$

Source: Own calculations.

\section{APPENDIX D}

Table 4. Estimation Results.

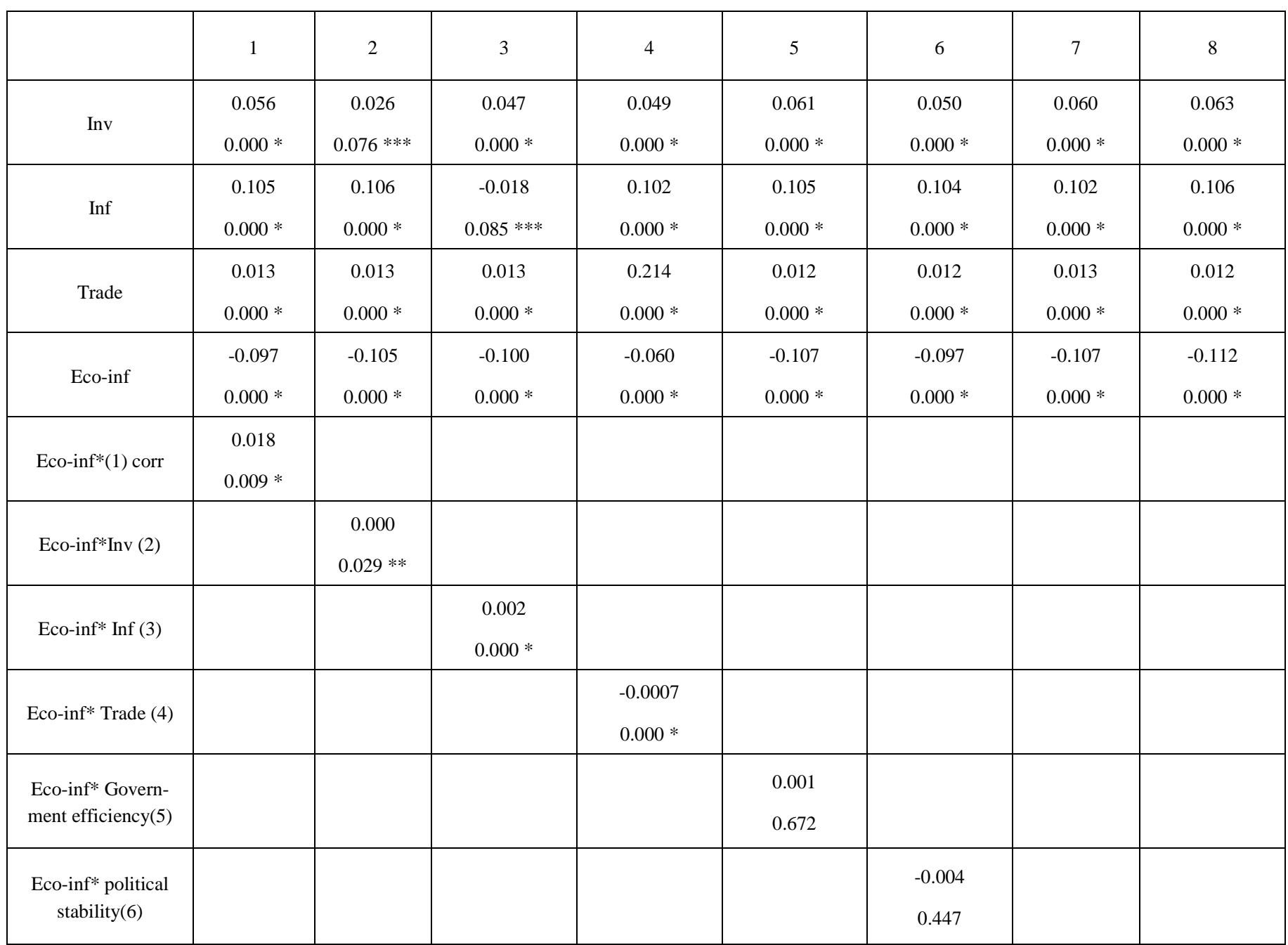




\begin{tabular}{|c|c|c|c|c|c|c|c|c|}
\hline $\begin{array}{c}\text { Eco-inf* regulatory } \\
\text { quality }(7)\end{array}$ & & & & & & & $\begin{array}{l}-0.015 \\
0.000 *\end{array}$ & \\
\hline $\begin{array}{c}\text { Eco-inf* Rule of } \\
\text { law(8) }\end{array}$ & & & & & & & & $\begin{array}{l}-0.018 \\
0.000 *\end{array}$ \\
\hline AR (1) & $\begin{array}{c}-4,450 \\
0.000\end{array}$ & $\begin{array}{c}-4.414 \\
0.000\end{array}$ & $\begin{array}{l}-4.486 \\
0.000\end{array}$ & $\begin{array}{l}-4.555 \\
0.000\end{array}$ & $\begin{array}{l}-4.258 \\
0.000\end{array}$ & $\begin{array}{l}-4.443 \\
0.000\end{array}$ & $\begin{array}{l}-4.418 \\
0.000\end{array}$ & $\begin{array}{l}-4.378 \\
0.000\end{array}$ \\
\hline AR (2) & $\begin{array}{l}-1.675 \\
0.000\end{array}$ & $\begin{array}{r}-1.699 \\
0.000\end{array}$ & $\begin{array}{l}-1.572 \\
0.115\end{array}$ & $\begin{array}{l}-1.676 \\
0.103\end{array}$ & $\begin{array}{l}-1.730 \\
0.083\end{array}$ & $\begin{array}{l}-1.722 \\
0.085\end{array}$ & $\begin{array}{r}-1.699 \\
0.000\end{array}$ & $\begin{array}{l}-1.692 \\
0.000\end{array}$ \\
\hline Sargan & $\begin{array}{r}47,450 \\
1,000\end{array}$ & $\begin{array}{r}47,737 \\
1,000\end{array}$ & $\begin{array}{r}48,435 \\
1,000\end{array}$ & $\begin{array}{r}48,708 \\
1,000\end{array}$ & $\begin{array}{c}44,172 \\
1,000\end{array}$ & $\begin{array}{c}48,287 \\
1,000\end{array}$ & $\begin{array}{c}49,743 \\
1,000\end{array}$ & $\begin{array}{r}48,383 \\
1,000\end{array}$ \\
\hline
\end{tabular}

Note: $* * * \mathrm{p}<0.01, * * \mathrm{p}<0.05, * \mathrm{p}<0.1$

Source: Own calculations.

\section{REFERENCES}

Ben C. Arimah (2001). Nature and Determinants of the Linkages between Informal and Formal Sector

Enterprises in Nigeria; African development review, vol 13, Pages 114-144. https://doi.org/10.1111/1467-8268.00033

Borlea et al., 2017, Corruption, Shadow Economy and Economic Growth: An Empirical Survey Across the

European Union Countries: Journal of Applied Engineering Sciencei 27 (2)

https://doi.org/10.1515/sues-2017 0006.

Djankov et al (1, February 2002), The Regulation of Entry, The Quarterly Journal of Economics, Volume 117, Pages 1-37. https://doi.org/10.1162/003355302753399436

Friedrich Schneider and Hametner Bettina, (2014), The Shadow Economy in Colombia: Size and Effects on Economic Growth, Peace Economics, Peace Science, and Public Policy, 20. (2), 33 http // : 10.1515/peps-2013-0059

Friedrich Schneider with the collaboration of Dominik Enste,"Under the protection of the shadows The growth of the underground economy" March 2002

Goel, Rajeev K. and Saunoris, James W. and Schneider, Friedrich G., Drivers of the Underground Economy Around the Millienium: A Long Term Look for the United States. IZA Discussion Paper No. 10857, http://hdl.handle.net/10419/170841

Jean-François Bickel. "Interaction effect", statistic II https://docplayer.fr/42077585

Jacquot Yves-Marie, Schwander Jérôme (2000), License Analysis and Economic Policies. http://www.vcharite.univmrs.fr/PP/yildi/croissance/dos9900/commerce

Mandroshchenko et al., 2018, "Influence of the shadow economy on economic growth", Journal of Applied Engineering Science 87-94. http //: 10.5937/jaes16-16490

Medina, Leandro and Schneider, Friedrich G., Shadow Economies Around the World: New Results for 158 Countries Over 1991-2015 (April 10, 2017). CESifo Working Paper Series No. 6430 SSRN: https://ssrn.com/abstract=2965972.

Michał Jerzmanowski, 2017. "Finance and sources of growth: evidence from the US states, "Journal of Economic Growth, Springer, vol. 22 (1), pages 97-122, March. DOI: 10.1007/s10887-016-9135-6

Nicolini, Juan Pablo, 1998. "Tax evasion and the optimal inflation tax", Journal of Development Economics, Elsevier, vol. 55 (1), pages 215-232, February.

http://www.sciencedirect.com/science/article/pii/S0304 3878(97)00063-1

Norman Loayza, (1996), The economics of the informal sector: a simple model and some empirical evidence from Latin America, CarnegieRochester Conference Series on Public Policy, 45, (1), 129-162 https://doi.org/10.1016/S0167-2231(96)00021-8

Oasis Kodila-Tedika, Mihai Mutascu: Shadow economy and tax revenue in Africa, Economics Bulletin 34 (1): 469-479, January 2014 Handle: RePEc:ebl:ecbull:eb-13-00777

Ottervik M. (2013): Conceptualizing \& Measuring State Capacity: Testing the Validity of Tax Compliance as a Measure of State Capacity, Working Paper No. 2013: 20, The Quality of Government Institute, Department of Political Science, University of Gothenburg, Gothenburg, Sweden

Yasir Ali Mubarik, (2005), Inflation and Growth: An Estimate of the Threshold Level of Inflation in Pakistan, SBP Research Bulletin, 1, 35-44.http://www.sbp.org.pk/repec/sbp/journ1/Article-3.pdf

Zaman and Goschin, (2015), Shadow Economy and Economic Growth in Romania. Cons and Pros, Procedia Economics and Finance, vol 22 Pages 80-87.https://doi.org/10.1016/S2212-5671(15)00229-4

Copyright @ 2021- All Rights Reserved

This is an open-access article. 